\title{
Fishing power, efficiency and selection of gillnets for the shortfin grunt (Microlepidotus brevipinnis Steindachner, 1869), in the southern coast of Jalisco, Mexico
}

\author{
Poder de pesca, selectividad y eficiencia de las redes de enmalle para la Sarangola \\ (Microlepidotus brevipinnis Steindachner, 1869) en la costa sur de Jalisco, México
}

\author{
Jorge A. Rojo-Vázquez ${ }^{1,3}$, Francisco Arreguín-Sánchez ${ }^{2}$, Enrique Godínez-Domínguez ${ }^{1}$ \\ ${ }^{1}$ Centro de Ecología Costera, Departamento de Ecología y Recursos Naturales, Universidad de Guadalajara. \\ Gómez Farias 82, San Patricio-Melaque, Jalisco. México 48980. \\ ${ }^{2}$ Centro Interdisciplinario de Ciencias Marinas del Instituto Politécnico Nacional. \\ Apartado Postal 592, 23000, La Paz, Baja California Sur, México. \\ ${ }^{3}$ Dirección actual: Centro de Investigación Científica y de Educación Superior de Ensenada, B.C. \\ Km 107 Carretera Tijuana-Ensenada. Apdo. Postal 2732. Ensenada, B. C. México. \\ jrojo@cicese.mx
}

\begin{abstract}
Resumen.- Con el fin de determinar la selectividad, poder de pesca y eficiencia de las redes de enmalle para la sarangola Microlepidotus brevipinnis (Steindachner, 1869) en la zona de Bahía de Navidad, Jalisco, se efectuaron muestreos mensuales de la captura obtenida con redes de 7,62 y 8,89 cm de luz de malla, de abril de 1994 a marzo de 1995. Los resultados indican que la red de $8,89 \mathrm{~cm}$ de tamaño de malla captura organismos en promedio $3 \mathrm{~cm}$ más grandes y $110 \mathrm{~g}$ más pesados que los capturados por la red de 7,62 cm. La red de 7,62 cm obtiene 1,9 veces más organismos por lance y 1,3 veces más biomasa por lance que la obtenida por la red de 8,89 . En el análisis de selectividad, se obtuvo una longitud óptima (100\% de probabilidad de retención) de 27,7 y 32,2 $\mathrm{cm}$ de longitud total para las redes de 7,62 y 8,89 cm de luz de malla, respectivamente. La eficiencia de una red con respecto a la otra cambia en una proporción entre 25 y 39\% conforme aumenta la talla de los peces .

Palabras clave: Microlepidotus brevipinnis, redes de enmalle, selectividad, poder de pesca, capturabilidad, Jalisco, México.
\end{abstract}

\begin{abstract}
Gillnet selectivity, fishing power and catch efficiency for Microlepidotus brevipinnis (Steindachner, 1869) off Bahia de Navidad, Jalisco, Mexico, were estimated. Field experiments were conducted using gillnets of 7.62 and $8.89 \mathrm{~cm}$ of mesh-size, during April 1994 to March 1995. A total of 457 organisms were caught with the $7.62 \mathrm{~cm}$ meshsize, and 592 with the 8.89 mesh-size. Results shows gillnet of $8.89 \mathrm{~cm}$ mesh size caught $3 \mathrm{~cm}$ larger organisms and $110 \mathrm{~g}$ more weighted fish than those caught by the 7.62 mesh-size. The 7.62 mesh-size caught 1.9 times organisms and 1.3 more weight than the $7.62 \mathrm{~cm}$ mesh-size. Selectivity analysis indicates an optimum length (100\% probability of retention) was $27.7 \mathrm{~cm}$ TL for the 7.62 mesh-size and $32.3 \mathrm{~cm}$ TL for the $8.89 \mathrm{~cm}$ mesh-size. The relative efficiency analysis was estimated as relative catchability ratio between nets and it varied in a range of $25 \%$ to $39 \%$ with fish length.

Keywords: Microlepidotus brevipinnis, gillnet, selectivity, fish power, catchability, Jalisco, Mexico.
\end{abstract}

\section{Introduction}

Microlepidotus brevipinnis (Steindachner, 1869) is the most important fish species for the gillnet fishery in the southern coast of Jalisco, Mexico (Rojo \& Ramírez 1997). Such as other Haemulid fish, M. brevipinnis presents schools on sandy areas, usually between 5 and $30 \mathrm{~m}$ of depth. This fish reaches $40 \mathrm{~cm}$ of total length, TL, and is distributed from the Gulf of California to Peru (Allen \& Robertson 1994, Fischer et al. 1995).

Gillnets are common fishing gears in the artisanal fisheries, which provide large yields respect to other fishing gears (Hamley 1975, González et al. 1995). The knowledge of selectivity and efficiency of the fishing gears are of importance for management purposes, since an appropriate mesh-size will help to maximize yields and minimize the loss of small fish that already have been caught (Hamley 1975).

This work is aimed to estimate and to know some properties of the fishing gear such as the probability of selection, fishing power and the relative efficiency for gillnets used to catch the shortfin grunt from Bahía de Navidad, Jalisco, Mexico. 


\section{Material and Methods}

Field data and samples were obtained from a monthlybasis during April-1994 to March-1995. Experimental fishing with gillnets of two mesh-size was accomplished during the night; the gillnets were randomly located on different sites within the fishing grounds and they were maintained in operation during the same time conditions. Gillnets were designed to operate at bottom and were placed in a range of depth, between 7 and 12 $\mathrm{m}$. Places selected to fishing have on similar type of bottom (sandy and small stones). Fishing grounds were close Melaque, Corrales, Coastecomate, El Estrecho and El Palmito (Fig. 1).

Gillnets used were constructed with nylonmonofilament, with a mesh-size of $7.62 \mathrm{~cm}$ (3.0 in) and $8.89 \mathrm{~cm}$ (3.5 in), a height of $4.5 \mathrm{~m}, 120 \mathrm{~m}$ length and a hanging ratio of 0.65 . All fish caught were measured as total length (TL cm) and total weight (TW g).

To analyze the fishing power we used lengthfrequency distributions expressed by the catch-per-unit- effort (U) as number of fish per fishing day (org/f.d.). Relative fishing power between nets was estimated by regressing the catch-per-unit-effort among nets. The hypothesis behind this experiment is based on the idea that if two gears operate simultaneously in time and space and they have the same fishing power, the slope the straightforward line described above should be equal to the unit $(b=1)$. Therefore, the value of the slope is an index of the relative fishing power of a gear respect to the other.

Probability of selection was estimated following Holt (1963). Input data were numbers caught by length-class by fishing gear and their corresponding mesh-sizes. The length-classes were of $2.5 \mathrm{~cm}$. Catch ratios were computed as logarithm of catches per length-class considering the range of length overlapping each other.

This catch ratio per length-class can be regressed to the mid-length class describing a linear function (van Densen 1987, Sparre \& Venema, 1995) as follows

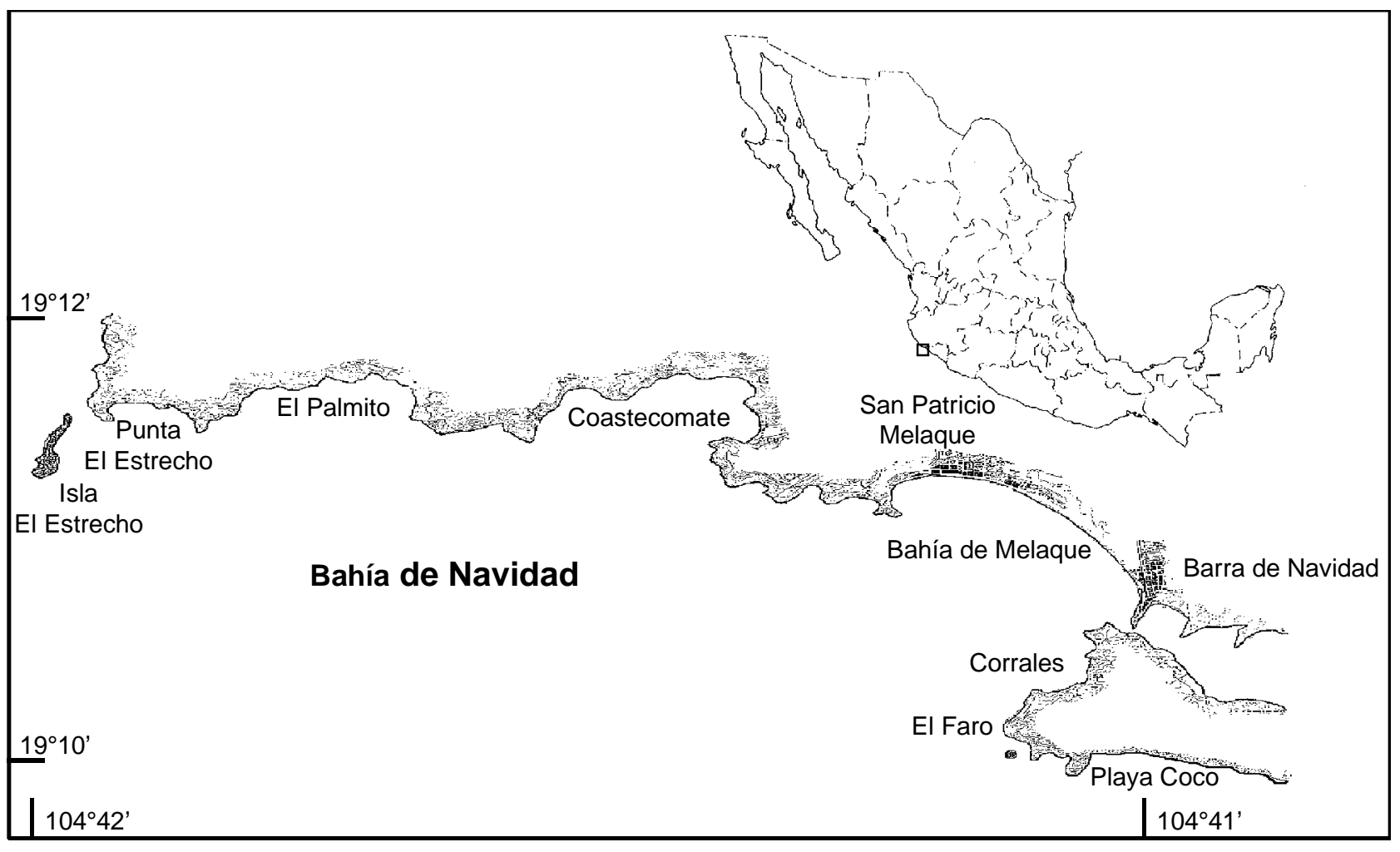

Figure 1

Study area: Bahia de Navidad, Jalisco, Mexico.

Área de estudio: bahía de Navidad, Jalisco, México. 


$$
\ln \left(\frac{C b}{C a}\right)=\alpha+\beta * L
$$

where $\mathrm{C}$ is the catch in number of organisms, $\mathrm{a}$ and $\mathrm{b}$ are gillnet type index, $\mathrm{L}=$ mid-length class, $\alpha$ and $\beta$ are parameters of the model.

The selection factor, SF, was estimated through the equation:

$$
\mathrm{SF}=\frac{-2 * \alpha}{\beta^{*}(\mathrm{ma}+\mathrm{mb})}
$$

where, $\alpha$ and $\beta$ are as above, ma and mb are the meshsize for gear $a$ and $b$.

The optimum length (corresponding to a $100 \%$ of probability of retention) for each mesh-sizes was obtained as: $\mathrm{Lma}=\mathrm{SF}^{*} \mathrm{ma}$ and $\mathrm{Lmb}=\mathrm{SF}^{*} \mathrm{mb}$, and the probability of selection was computed from

$$
S L=e\left(\frac{(L-L m)^{2}}{2 * s^{2}}\right)
$$

where SL is the probability of selection for a fish of length $\mathrm{L}$; $L m$ it is the optimum length, and $s$ is the common standard deviation for both nets estimated as

$$
s^{2}=\frac{-2 * \alpha *(m b-m a)}{\beta^{2 *}(m a+m b)}
$$

and

$$
\mathrm{SF}=\frac{\mathrm{mb}-\mathrm{ma}}{\beta}=\mathrm{s}^{2}
$$

Parameters and selection curves were estimated by using the routine provided by the FiSAT program (Gayanilo et al. 1995).

Estimate of relative efficiency for gillnets were obtained following Arreguín (1996) and Arreguín \& Pitcher (1999) who used the relationship

$$
\ln \left[\frac{\mathrm{u} \ell, \mathrm{a}^{\mathrm{a}}}{\mathrm{u} \ell, \mathrm{b}}\right]=\ln \left[\frac{\mathrm{q}_{\ell, \mathrm{a}} \mathrm{N}_{\ell}}{\mathrm{q}_{\ell, \mathrm{b}} \mathrm{N}_{\ell}}\right]=\ln \left[\frac{\mathrm{q}_{\ell, \mathrm{a}}}{\mathrm{q}_{\ell, \mathrm{b}}}\right]
$$

where $U$ is the catch-per-unit-effort, $\ell$ is the index for length-class, $\mathrm{q}$ the catchability coefficient, as a measure of efficiency, $\mathrm{N}$ the stock size, $\mathrm{a}$ and $\mathrm{b}$ as above represent the fishing gears.

The catch-per-unit-effort ratio can be expressed as a linear function of the mid-length- class as:

$$
\ln \left[\frac{\mathrm{u}_{\ell, \mathrm{a}}}{\mathrm{u} \ell, \mathrm{b}_{\mathrm{b}}}\right] \cong \ln \left[\frac{\mathrm{q}_{\ell, \mathrm{a}}}{\mathrm{q}_{\ell, \mathrm{b}}}\right]=\alpha+\beta \bar{\ell}
$$

where:

$$
\beta=\ln \left[\frac{\mathrm{q}_{(\ell+1) \mathrm{a}}}{\mathrm{q}_{\ell, \mathrm{a}}}\right]-\ln \left[\frac{\mathrm{q}_{(\ell+1) \mathrm{b}}}{\mathrm{q}_{\ell, \mathrm{b}}}\right]
$$

which is interpreted as the rate of change of $q_{\ell, a}$ with respect to $q_{\ell, b}$, in other words, how the efficiency of the net a changes respect to net $\mathrm{b}$ as length-class increase. A positive values indicate that net a is more efficient to capture small sizes and less efficient for larger fish, while negative values indicate the opposite. When this ratio equals zero, efficiency of both nets is equal.

For the calculation of the relative efficiency between nets with different mesh-sizes we used two criteria: the length-classes belonging to the selection ranges of each net and, common length-classes for those selection ranges.

\section{Results}

Fishing power. Catch-per-unit-effort in number of fish and weight (per fishing day), for M. brevipinnis was obtained. The gillnet of $7.62 \mathrm{~cm}$ caught 457 organisms weighting $103.1 \mathrm{~kg}$. The average weight was $0.22 \mathrm{~kg}$ and the mid-length $24.2 \mathrm{~cm}$ TL. The gillnet of $8.89 \mathrm{~cm}$ caught 592 fishes with a total weight of $201.3 \mathrm{~kg}$, an weight and length of $0.33 \mathrm{~kg}$ and $27.4 \mathrm{~cm} \mathrm{TL}$, respectively. Catch-per-unit-effort in number was of 9.3 organisms/f.d. for the net of $7.62 \mathrm{~cm}, 1.9$ times than the net of $8.89 \mathrm{~cm}$. In terms of weight the net of $7.62 \mathrm{~cm}$ obtained $2.1 \mathrm{~kg} / \mathrm{f} . d$. , meaning 1.3 times than net of 8.89 . There was not significant relationship between fishing power for gillnets used, probably because the high variance observed (Fig. 2).

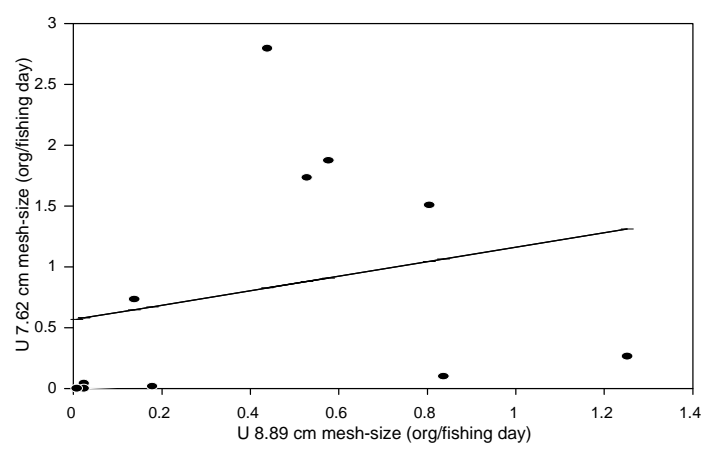

Figure 2

Comparison of the fishing power from gill nets with $7.62 \mathrm{~cm}$ and 8.89 mesh size, used in Bahia de Navidad, Jalisco, Mexico. $\mathrm{U}=$ Catch per unit effort.

Comparación del poder de pesca de redes de enmalle con luz de malla de 7,62 cm y 8,89 cm, utilizadas en Bahía de Navidad, Jalisco, México.

$\mathrm{U}=$ Captura por Unidad de Esfuerzo 
The catch-per-unit-effort by season shows similar variation, in weight as well as in number, but such variation was different between nets. In the net of 7.62 $\mathrm{cm}$ maximum values during summer and winter were similar, and the minimum values during autumn (Fig. $3 a)$. On the other hand, the net of $8.89 \mathrm{~cm}$ shows a seasonal pattern with a lower value of variation in summer and maximum during winter (Fig. 3b).

Selectivity. For this analysis a total of 457 data of the $7.62 \mathrm{~cm}$ mesh-net and 592 for the $8.89 \mathrm{~cm}$ mesh-net were available. Lengths of fish varied between 17 and $39.9 \mathrm{~cm}$ TL and presented an average length of $24.0 \mathrm{~cm}$ TL for the $7.62 \mathrm{~cm}$ mesh-net, and $27.5 \mathrm{~cm}$ TL for the $8.89 \mathrm{~cm}$ mesh-net. The standard deviation of the sample obtained by the net of $7.62 \mathrm{~cm}$ mesh was of $3.3 \mathrm{~cm}$, and $4.6 \mathrm{~cm}$ for the $8.89 \mathrm{~cm}$ mesh.
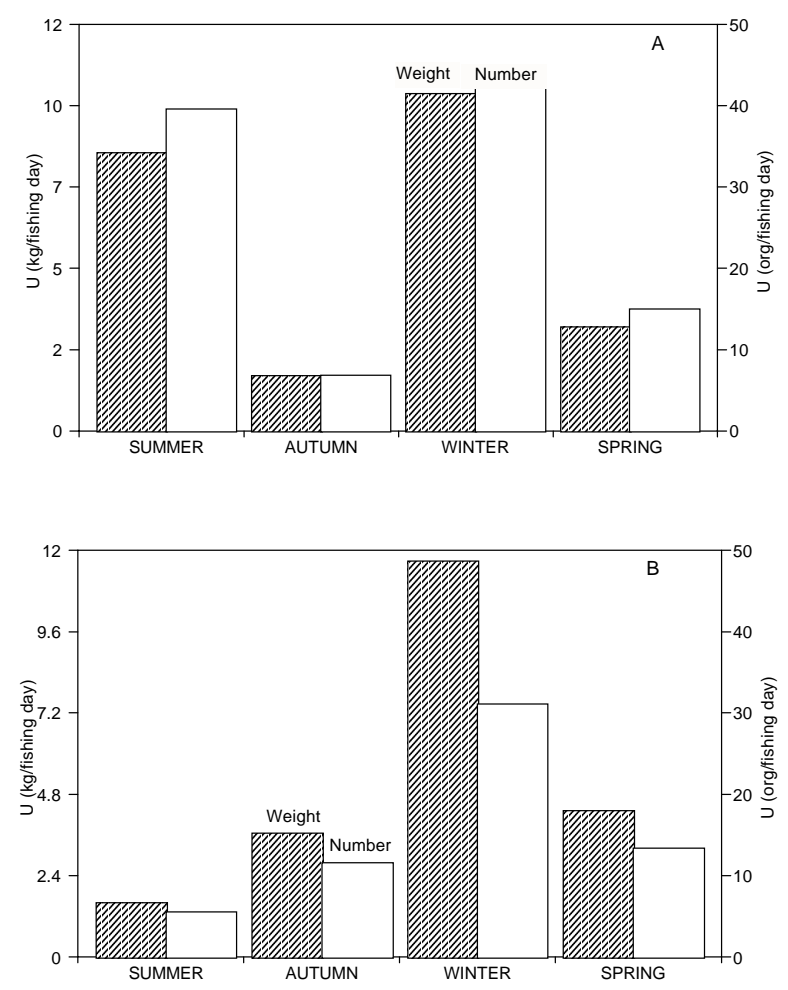

Figure 3

Seasonal comparison of the catch per unit effort obtained with gill nets of $7.62 \mathrm{~cm}$ (A) y $8.89 \mathrm{~cm}$ (B) mesh size, from en Bahia de Navidad, Jalisco, Mexico.

Comparación estacional de la captura por unidad de esfuerzo obtenida con redes de enmalle de 7,62 cm (A) y 8,89 cm (B) de luz de malla, en Bahía de Navidad, Jalisco, México.

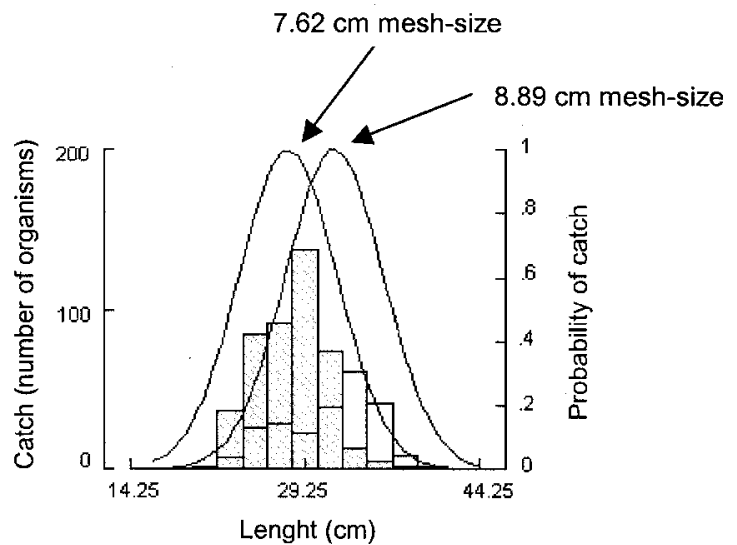

Figure 4

Gill nets selectivity curves obtained with the Holt (1963) method. The optimum length calculated was $27.7 \mathrm{~cm}$ and 32.3 respectively for the 7.62 and $8.89 \mathrm{~cm}$ mesh size, with a standard deviation $=\mathbf{4 . 9 0 4}$.

Curvas de selectividad para redes de enmalle obtenidas mediante el método de Holt (1963). La longitud óptima calculada fue de $27,7 \mathrm{~cm}$ y $32,3 \mathrm{~cm}$ respectivamente para las redes de 7,62 cm y 8,89 cm de luz de malla, con una desviación estándar $=4,904$.

The optimum lengths were $\mathrm{L}_{50}=27.7 \mathrm{~cm} \mathrm{TL}$ and $\mathrm{L}_{50}=32.3 \mathrm{~cm}$ TL for the net of 7.62 and $8.89 \mathrm{~cm}$ meshnet respectively and a common standard deviation of 4.904 (Fig. 4). The selection range was of 19.5 to 34.5 $\mathrm{cm}$ and of 24.5 to $39.5 \mathrm{~cm}$, respectively; and the selection factor of 3.70 .

Relative efficiency between gillnets. Parameter for equation (1) were: $\alpha=-5.77, \beta=0.191$ and the correlation coefficient $\mathrm{r}=0.807\left(\mathrm{~F}_{\alpha=0.05}=11.64\right.$, d.f. $=$ $8, p=0.011)$. In the calculation of the relative efficiency of the gears, the slope represents the rate of change that has the catchability with the length. This results indicate the net of $7.62 \mathrm{~cm}$ mesh is more efficient than the net of 8.89 mesh to catch small fishes, but this relationship is opposite for large fish.

Taking $\beta$ as a measure of the relative efficiency, and for the case where all the selection range of both nets was used, the difference in the efficiency was $25 \%$. This relative change of efficiency with fish-length was significant $\left(\mathrm{r}=-0.89, \mathrm{~F}_{\mathrm{a}=0.05}=22.96\right.$, d.f. $=7, \mathrm{P}=0.003$, Fig. 5a). This means that if fish-length increases, efficiency for the net of $7.62 \mathrm{~cm}$-mesh reduces in a $25 \%$, while for the net of $8.89 \mathrm{~cm}$-mesh increases on the same magnitude. On the other hand, when common lengths, within the selection range, were used, differences in relative efficiency resulted in 39\% $\left(\mathrm{r}=-0.908, \mathrm{~F}_{\mathrm{a}=0.05}=\right.$ 14.14, d.f. $=4, \mathrm{P}=0.032, \mathrm{~L}_{50}=\mathrm{L}_{50}=$ Fig. $5 \mathrm{~b}$ ). 

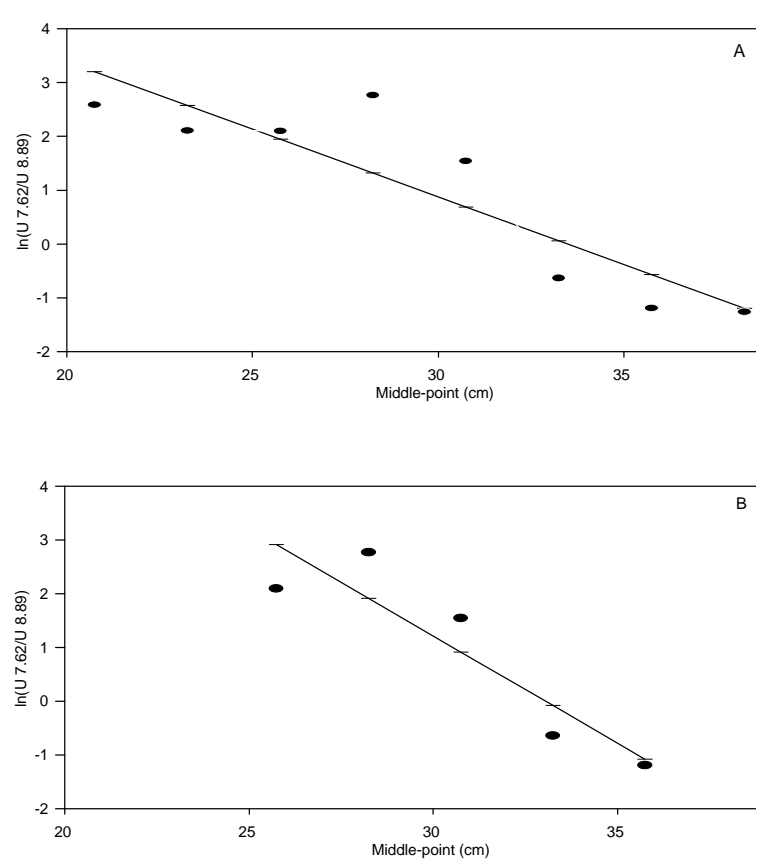

Figure 5

Relative efficiency for the gill nets of $7.62 \mathrm{~cm}$ and $8.89 \mathrm{~cm}$ mesh size. (A) using all the range of selection from both gill nets and, (B) using only the common lengths for both range of selection.

Eficiencia relativa para las redes de enmalle de 7,62 cm y 8,89 $\mathrm{cm}$ de luz de malla. (A) utilizando todo el intervalo de selección de amas redes, (B) utilizando solamente las longitudes comunes a ambos intervalos de selección.

\section{Discussion and Conclusion}

Analysis of fishing power indicates no significant difference between gillnets so that in global terms there is no difference between them. However the catch-perunit-effort exhibits a different seasonal pattern between nets. This suggest a type of selection associated to each net.

The study of the selectivity and efficiency of the fishing gears constitute a tool of great importance for fishery managers, who used this information to control fishing mortality through the size of fish.

Relative efficiency shows a difference between gillnets and as well as with length; contrarily to the common assumption of a constant catchability value. The slope of the relationship in equation (4) indicates important differences between nets. When $\beta$ is negative means gillnet of $7.62 \mathrm{~cm}$ mesh-size is more efficient for small fish than larger ones, respect to the gillnet of 8.89 $\mathrm{cm}$ mesh-size. The opposite will occurs when slope changes sign.
Borgstrom (1992) suggests habitat interactions could affect efficiency. In our case, since gillnets operated on the same area and time; and lasted the same time operating, this effect was, at least, minimized. Another factor affecting efficiency could be the particular behavior of fish to a specific gear causing different accessibility, or even interference between fishing gears. None of both cases were tested in this work, however, given the experimental conditions we do not expect a strong impact of these factors on our results.

Selectivity analysis suggests catch is concentrated in a few range of lengths, $(17$ to $39.9 \mathrm{~cm}$ for the $7.62 \mathrm{~cm}$ mesh-size, 24.5 to $39.5 \mathrm{~cm}$ for the $8.89 \mathrm{~cm}$ mesh-size, with a selection factor of 3.7).

These data confirms the fact that gillnets are high selective gears as mentioned many years ago by Baranov (1948), who stated that this fishing gears retain fish of lengths no more than $20 \%$ of the optimum length. Different authors such as Grant (1981), Nakatani et al. (1991), De Silva \& Sirisena (1987) also have reported this. In our study case curves overlaps about $80 \%$ of the range of length which explains why fishing power between nets were not significantly different.

\section{Acknowledgments}

This work was financed by the University of Guadalajara, under permit SEMARNAP 070794/310/03/1777. Our thanks to the crew of the ship Leon Marino for the samples. The first author thanks to CONACYT and University of Guadalajara because support. The second author thanks to Instituto Politécnico Nacional because support given through CEGEPI-980056, COFFA and EDD.

\section{Literature Cited}

Arreguín SF. 1996. Catchability: a key parameter for fish stock assessment. Reviews in Fish Biology and Fisheries 6: 221-242.

Arreguín SF \& TJ Pitcher. 1999. Catchability estimates and their application to the red grouper (Epinephelus morio) fishery of the Campeche Bank, Mexico. Fishery Bulletin 97: 746-757.

Allen GR \& DR Robertson. 1994. Fishes of the tropical eastern Pacific. Univ. of Hawaii Press. 332 p.

Baranov FI. 1948. The theory and assessment of fishing gear. Pishchepromisdat, Moscow. (Ch. 7 Theory of fishing with gill nets) Trans. from Russian by Ont. Dep. Lands For. Maple, Ont., 45 p.

Borgstrom R. 1992. Effect of population density on gilnet catchability in four allopatric populations of brown trout (Salmo trutta). Canadian Journal of Fisheries and Aquatic Science 49: 1539-1545. 
De Silva SS \& HKG Sirisena. 1987. New fish resources of reservoirs in Sri Lanka: Feasibility of introduction of a subsidiary gillnet fishery for minor cyprinids. Fisheries Research 6: 17-34.

Fischer FK, W Schneider, C Sommer, KE Carpenter \& NH Niem. 1995. Guía FAO para la identificación de especies para fines de la pesca. Pacífico Centro-Oriental. Vols II and III. Vertebrados Parts 2 and 3: $647-1813$.

Gayanilo FCJr., P Sparre \& D. Pauly. 1995. The FAOICLARM Stock Assessment Tools (FiSAT) User's guide. FAO Computerized Information Series (Fisheries). No. 8. Rome, Italy. 126 p.

González JA, JI Santana, V Rico, VM Tuset \& MM García. 1995. Descripción de la pesquería de enmalle en el sector Norte Noreste de Gran Canaria. Informe Técnico Instituto de Ciencias Marinas. 1. Telde (Gran Canaria). 59 p.

Grant CJ. 1981. Gill net selectivity and catch rates of coastal pelagic fish in Jamaica. Estuarine, Coastal and Shelf Science 12: 167-175.
Hamley JM. 1975. Review of gillnet selectivity. Journal of the Fisheries Resource Board of Canada 32: 1943-1969.

Holt SJ. 1963. A method for determining gear selectivity and its application. ICNAF-ICES-FAO Joint Scientific Meeting, Spec. Publ. No. 5.

Nakatani K, LC Gomes \& JD Latini. 1991. Seletividade em redes de espera para captura de Trachydoras paraguayensis (Osteichthyes, Siluriformes), no reservatorio de Itaipu e áreas de sua influencia. Revista. UNIMAR, Maringá 13(2): 327-338.

Rojo VJ \& Ramírez RM. 1997. Composición específica de la captura con redes de enmalle en Bahía de Navidad, Jalisco, México. Oceánides 12(2): 121-126.

Sparre P \& SC Venema. 1995. Introducción a la evaluación de recursos pesqueros tropicales. Parte 1. Manual. FAO Doc. Téc. Pesca. 306.1 Rev. 1. Roma, Italia. 427 p.

Van Densen WLT. 1987. Gillnet selectivity to pikeperch, Stizostedion lucioperca (L.), and perch, Perca fluviatilis L., caught mainly wedged. Aquaculture and Fisheries Management 18: 95-106.

Recibido en octubre de 2000 y aceptado en marzo de 2001 